\title{
Editorial
}

\section{The Persistence and Increase in Sexually Transmitted Diseases (STDs) to Pandemic Levels}

\author{
Luigi Santacroce $^{1, * \mathbb{D}}$, Marica Colella ${ }^{1}$ and Ioannis Alexandros Charitos ${ }^{2}$ \\ 1 Microbiology and Virology Unit, Department of Interdisciplinary Medicine, School of Medicine, \\ University of Bari, Piazza G. Cesare 11, 70124 Bari, Italy; marycolella98@gmail.com \\ 2 Interdepartmental Research Center for Pre-Latin, Latin and Oriental Rights and Culture Studies (CEDICLO), \\ University of Bari, Piazza Umberto I, 70123 Bari, Italy; alexanestesia@hotmail.com \\ * Correspondence: luigi.santacroce@uniba.it
}

\section{check for} updates

Citation: Santacroce, L.; Colella, M.; Charitos, I.A. The Persistence and Increase in Sexually Transmitted Diseases (STDs) to Pandemic Levels. Venereology 2022, 1, 2-8. https:/ / doi.org/10.3390/venereology1010002

Received: 27 October 2021

Accepted: 5 November 2021

Published: 9 November 2021

Publisher's Note: MDPI stays neutral with regard to jurisdictional claims in published maps and institutional affiliations.

\section{Copyright: (c) 2021 by the authors.} Licensee MDPI, Basel, Switzerland. This article is an open access article distributed under the terms and conditions of the Creative Commons Attribution (CC BY) license (https:// creativecommons.org/licenses/by/ $4.0 /)$.

\begin{abstract}
Sexually transmitted diseases (STDs) have been known about since ancient times. Today, however, STDs are on the rise in young people around the world. Interventions and sex education are being utilized in attempt to prevent STD spread in individuals who are the greatest risk of infection. Young people should be provided with easy and accessible health services. There should be anonymity as well as investigations into the reasoning behind unsafe behavior.
\end{abstract}

Keywords: sexually transmitted diseases; sexual health; prevention; syphilis; AIDS; HPV; gonorrhea

\section{Introduction}

Sexually transmitted diseases (STDs) incidence is on the in young people across the world. STDs are infections that are mainly transmitted through sexual intercourse. These diseases can be caused by bacteria, viruses, fungi, and parasites, including protozoa. STD classifications are based on causative agents (Table 1) [1].

Some STDs have been known about since ancient times (e.g., scabies and syphilis); society, since the time of Hippocrates, has focused on the prevention and therapy of these STDs [2,3]. Indeed, scabies has been mentioned by the ancient Chinese, Egyptians, Indians, Greeks, and Arabs. Aristotle (384-322 BC) mentioned a disease called $\psi \omega \hat{\omega} \rho \alpha$ (scabies) in

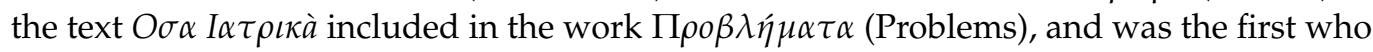
use the term $\alpha \kappa \alpha \rho \iota$ (àkari = mites). Subsequently, in 1687, the Italians, Giovanni Cosimo Bonomo (1666-1696) and Diacinto Cestoni (1637-1718), described the mite as a "small turtle", while in 1834, Simon François Renucci (1794-1874) successfully managed to remove these parasites from the skin of patients [4,5]. Syphilis and gonorrhea are other types of STDs. According to one currently accepted hypothesis, syphilis was carried to Europe via the crewmembers of Christopher Columbus, who were infected by the causative agent in the Americas [6]. The first recorded cases of syphilis was in 1494, in the French troops besieging Naples; the disease subsequently spread across Europe, killing more than five million people.

Other sailors were responsible for spreading gonorrhea from Tahiti to New Zealand via James Cook's (1728-1779) voyages. Later, Benjamin Bell (1749-1806) described the clinical differences between gonorrhea and syphilis, in 1793. The progress of three prominent stages of a syphilitic patient were described in 1838 by the French physician Philippe Ricord (1800-1889) (Figure 1) [6,7]. Subsequently, in 1879, Albert L. Neisser (1855-1916) identified the cause of gonorrhea. With the development of Wasserman's serological tests (WR), by August von Wassermann (1866-1925), the control and evaluation of the spread of infection was possible. Later, the discovery of antibiotics revolutionized his treatment [8]. During the 18th and 19th centuries, mercury, arsenic, and sulfur were generally used to treat sexually transmitted diseases, but unfortunately, they led to severe toxic side effects, even death (e.g., via mercury poisoning). Subsequently, the first effective treatment for syphilis was called "Salvarsan" in 1910 [6]. 
Table 1. The sexually transmitted diseases (STDs) are distinguished in five groups, according to causal factors.

\begin{tabular}{|c|c|c|c|c|}
\hline Basterial & Vingl & STDs Causal Factor & Protorou & Paracitic \\
\hline $\begin{array}{ll}\text { - } & \text { Syphilis (caused by } \\
\text { Treponema pallidum } \\
\text { subsp. pallidum) } \\
\text { Gonococcal } \\
\text { urethritis } \\
\text { (Gonorrhea) and } \\
\text { pelvic inflammatory } \\
\text { disease (PID) } \\
\text { (caused by Neisseria } \\
\text { gonorrhoeae) } \\
\text { Non-gonococcal } \\
\text { urethritis and pelvic } \\
\text { inflammatory } \\
\text { disease (PID) } \\
\text { (Chlamydia } \\
\text { trachomatis, other) } \\
\text { Lymphogranuloma } \\
\text { venereum } \\
\text { (Chlamydia } \\
\text { trachomatis L1, L2, L3 } \\
\text { serotypes) } \\
\text { Chancroid or soft } \\
\text { ulcer (caused by } \\
\text { Haemophilus ducreyi) }\end{array}$ & $\begin{array}{ll}\text { - } & \begin{array}{l}\text { Genital warts } \\
\text { (caused by Human }\end{array} \\
\text { Papilloma Virus } \\
\text { (HPV)) } \\
\text { - } \quad \text { Genital herpes } \\
\text { (usually caused by } \\
\text { Herpes simplex } 2 \\
\text { (HSV-2)) } \\
\text { Molluscum } \\
\text { contagiosum } \\
\text { (caused by a } \\
\text { poxvirus, } \\
\text { Molluscum } \\
\text { Contagiosum Virus } \\
\text { or MCV) } \\
\text { Hepatitis B (caused } \\
\text { by HBV) } \\
\text { Hepatitis C (caused } \\
\text { by HCV) } \\
\text { Acquired } \\
\text { Immunodeficiency } \\
\text { Syndrome-AIDS } \\
\text { (caused by Human } \\
\text { ImmunoDeficiency } \\
\text { Virus or HIV, } \\
\text { serotypes 1-2) }\end{array}$ & $\begin{array}{l}\text { Thrushes both sex } \\
\text { (>90\% caused by } \\
\text { Candida albicans) }\end{array}$ & $\begin{array}{ll}\text { - } & \text { Trichomoniasis } \\
\text { (caused by } \\
\text { Trichomonas vaginalis) }\end{array}$ & $\begin{array}{ll}\text { - } & \text { Scabies (caused by } \\
\text { - } & \text { Sarcoptes scabiei) } \\
\text { Pediculosis pubis } \\
\text { (caused by Phthirus } \\
\text { pubis) }\end{array}$ \\
\hline
\end{tabular}

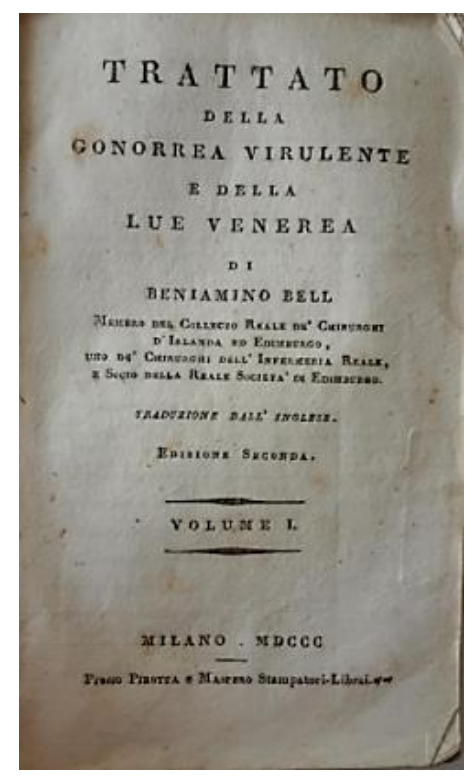

Figure 1. B. Bell, "Trattato delle gonorrea purulenta e della lue venerea" (A Treatise on Gonorrhoea Virulenta, and Lues Venerea, translated into Italian), Second edition, Publisher: Pirotta and Maspero, 1800.

Various pathogens can pass through injuries and abrasions of the skin or mucous membranes, no matter how small they are. Thus, STDs can occur through various routes. The main sources are usually secretions, such as saliva (rarely via stool, urine, or sweat) and mucosal or skin lesions (oral, vulvar, anal, urethral). They are infrequently transmitted through the mucous membranes of the upper respiratory tract (such as the larynx), or from the eyes. Other routes of transmission include incidents with blood transfusions (or other blood products), contaminated syringes (mainly in hospitals, laboratories, dental offices), and tattooing procedures. Many infections are not immediately detectable after contact/exposure; it takes time for diagnostic tests to be more accurate and detect the 
disease [9]. Finally, STDs can be transmitted from a mother to the fetus, as in cases of AIDS or syphilis that could occur during pregnancy (congenital syndromes), at childbirth, or through maternal breastfeeding. Many STDs are not immediately detectable after contact/exposure, and it will take some time for diagnostic tests to detect the disease [9]. Many factors influence the frequency and incidence of sexually transmitted diseases, e.g., an infected sexual partner, multiple sexual partners, drug abuse, movement from an endemic area, or poor sociocultural conditions (and, therefore, unhealthy conditions with poor personal hygiene). The aim of this paper was to determine the degree of the problem, with epidemiological data from Europe and America, and to find prevention methods (e.g., to prevent transmission). Furthermore, we highlight how to address STDs, as well as current knowledge and attitudes about prevention, and the various informative plans on STDs [10].

\section{The Epidemiological Data of STDs}

Between 1990 and 2000, there was an evident increase in viral diseases, such as Herpes Simplex 2 (HSV-2), Human Papilloma virus (HPV), Human Immuno Deficiency virus (HIV), and Cytomegalovirus (CMV) in Europe and America. In addition, there was a decrease in viruses of bacterial etiology, which were more frequent from the 1940s to the 1950s of the 20th century (such as syphilis, gonorrhea, venereal lymphogranuloma, and soft ulcers), and an increase in other viruses, such as non-gonococcal urethritis from C. trachomatis and fungal diseases [11-13].

According to the epidemiological surveillance report on sexually transmitted infections (STIs), from the European Centre for Disease Prevention and Control (ECDC), which covered the period from the 1990s to 2009, and focused on syphilis (also congenital), gonorrhea, chlamydia, and venereal lymphogranuloma (LGV), most STDs are asymptomatic, resulting in no diagnosis. About $60 \%$ of these infections occur in young people under the age of 25 and more than $30 \%$ are in individuals under the age of 20 . Between the ages of 14 and 19, STDs occur more often in girls, at a ratio of almost 2:1; at the age of 20 that ratio is 1:1. Among STDs, chlamydia infection was the most frequent in 2009, with 343,958 cases in 23 EU/EEA member states (except Bulgaria, Czech Republic, France, Germany, Italy, Liechtenstein, and Portugal). The total rate was 185 per 100,000 inhabitants, with a higher incidence in women (ratio 217 per 100,000) than in men (ratio 152 per 100,000). In addition, $75 \%$ of all cases were in the range $15-24$ years old, and young women were diagnosed with greater frequency than males. Chlamydia rates are increasing over time. Cases of gonorrhea were reported in 2009 in 28 EU/EEA member states, with a rate of 9.7 per 100,000 inhabitants. It was observed that this disease is more common in men (ratio 15.9 case per 100,000) than in women (ratio 6.3 case per 100,000), among which, $44 \%$ of cases were in individuals between 15 and 24 years old. In 2009, 18,279 cases of syphilis were reported from 28 EU/EEA member states at a rate of 4.5 per 100,000 inhabitants, which often prevailed in men (ratio 6.6 case per 100,000) than in women (ratio 2.2 case per 100,000). It was observed that, between the ages of 15 and 24 , the percentage of cases was $17 \%$, with most cases reported in people over 25 years old. Just over half (51\%) of syphilis cases were reported in men having sex with men. In the same report, 101 cases of congenital syphilis were reported (71 confirmed) from 23 countries. Between 1990 and 2009,1001 cases of congenital syphilis were reported by 24 EU/EEA countries, with an incidence of 3.5 per 100,000 births. In 2009, 245 cases of venereal lymphogranuloma from 5 EU/EEA countries were diagnosed, $98 \%$ male and $75 \%$ co-infected with HIV. Finally, this report shows that there are marked differences in trends across Europe. Indeed, the general trend of gonorrhea and syphilis across EU/EEA countries between 1999 and 2009 appeared to slightly decrease, showing a decreasing trend in countries that previously had higher rates than other countries, where continuous increases were observed. The general trend of Chlamydia trachomatis continues to grow, due to an increase in screening and diagnostic tests in several countries. Furthermore, syphilis and HSV-2 lead to an increased incidence 
of HIV infection. In fact, the number of people diagnosed with HIV during the period 2004-2010 increased by 18\%, up to a ratio of 6.6 cases per 100,000 in 2010 [14-16].

In 1999, a total of 659,441 cases of genital C. trachomatis infection were reported by the Centers for Disease Control and Prevention (CDC), USA, a rate of 254.1 cases per 100,000 people. This shows an increase of $8.5 \%$ from the rate of 234.2 of chlamydial infection reported in 1998 among women $(404.5$ per 100,000) compared to men (94.7 per $100,000)$, again reflecting a greater number of screened women. Following a $72 \%$ decline in the reported gonorrhea rate, from 1975 to 1997, the gonorrhea rate increased in 1999 for the second consecutive year. Finally, as for chlamydial infection, in women between 15 and 19 years old, gonorrhea rates are particularly high. The 6657 cases of primary and secondary syphilis reported in 1999 were the lowest number of these reported in the US since 1957. The syphilis rate of 2.5 cases per 100,000 people was the lowest of the 4 cases per 100,000 people reported in 1941. Between 1998 and 1999, the rate of congenital syphilis in the US decreased by $34 \%$, from 21.6 to 14.3 cases per 100,000 live births [17].

The 2013 report by the European Centre for Disease Prevention and Control (ECDC) shows that chlamydia is the most common sexually transmitted infection in the world (146 million infections every year), with Europe having nearly 385,000 cases (in 2013) and more than 3 million cases between 2004 and 2013 [18].

The rates of gonorrhea have increased by $79 \%$ since 2008 , particularly among men. Furthermore, in 2016, 29,365 syphilis cases were reported in 28 EU/EEA member states, with 33,189 in 2017. The incidence rate for 2016 was 6.1 cases per 100000 people, eight-fold higher in men than in women, and peaking among 25-34-year-old men (25 cases per 100,000) (Figure 2). Thus, the trend in syphilis rates has been on the rise since 2011, particularly among men, and rates among women increased slightly in 2016 and 2017 [19-21].

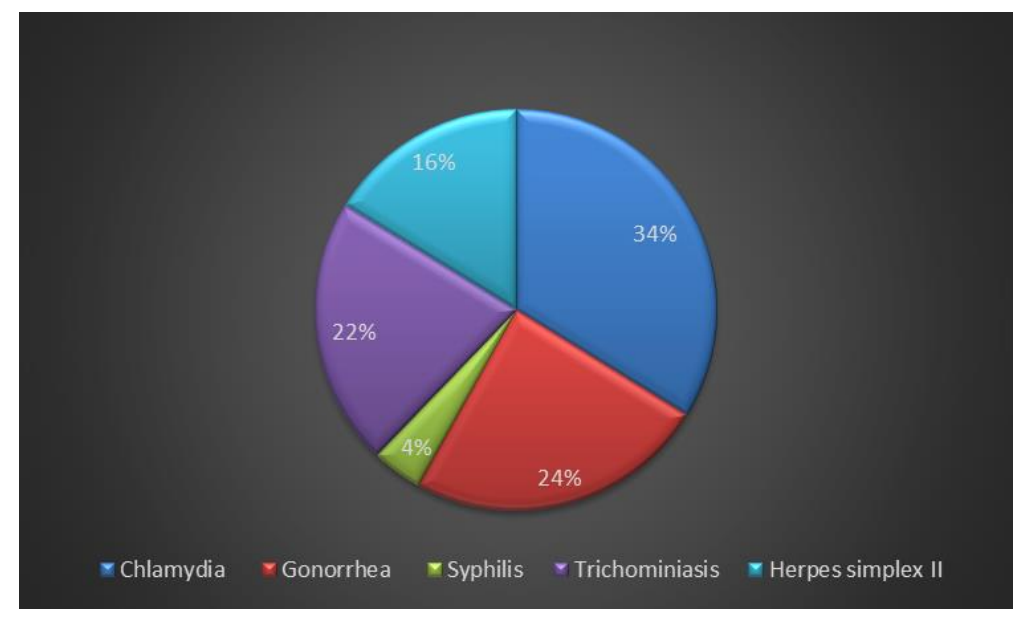

Figure 2. Adolescent females suffering from STDs in developing countries have been reported with and without lower genital symptoms. Among those with symptoms of urethritis, Chlamydia trachomatis (9-11\%) and Neisseria gonorrhoeae (2-3\%) have been isolated, respectively [18]. Credits: figure by I.A. Charitos.

Currently, according to recent World Health Organization (WHO) estimates, more than 376 million new cases occur each year (75-85\% in developing countries), regarding the four main diseases, gonorrhea, chlamydia, syphilis, and trichomoniasis. It was noted that 1 million new cases of infections occur among people between the ages of 15 and 49 [22]. The current report shows that, in men and women aged 15-49, there were 127 million new cases of chlamydia in 2016, 87 million gonorrhea cases, 6.3 million syphilis cases, and 156 million cases of trichomoniasis. In 2018, in the US, the majority of infections were caused by chlamydia, trichomoniasis, genital herpes, and HPV, regardless of age group. Hence, it represented $93 \%$ of all sexually transmitted diseases (such as HPV infection, which represented $50 \%$ of all infections, with $63 \%$ of all prevalent infections) [23]. 
In 2019, STDs statistics reported on by the CDC in the US, showed that there were 1.8 million cases of chlamydia, 616,392 cases of gonorrhea, 129,813 cases of syphilis (all stages), and nearly 2000 cases of congenital syphilis, which could cause permanent health problems, such as in the central nervous system (CNS) and peripheral nervous system (PNS), and lead to severe anemia, bone deformity, etc. (Figure 3) [24].

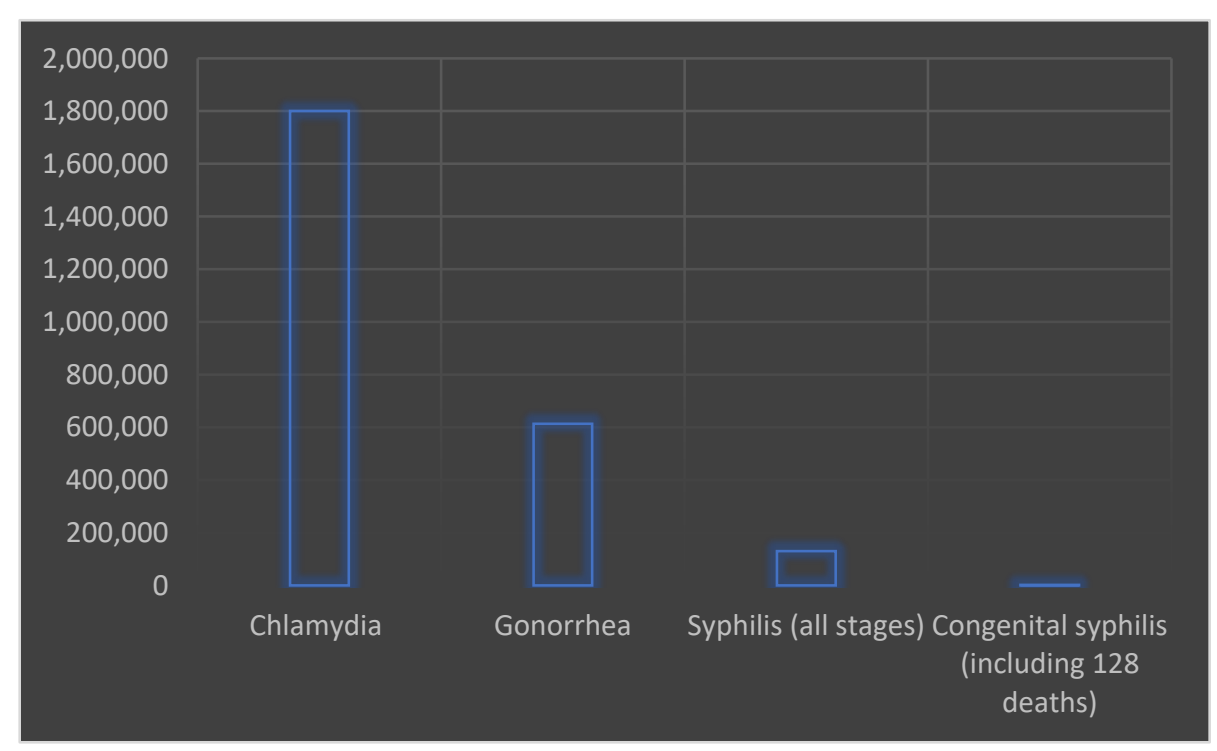

Figure 3. STDs in 2019. Since 2015, there has been an increase in chlamydia by nearly $20 \%$, gonorrhea by more than $50 \%$, syphilis (all stages) by more than $70 \%$, and congenital syphilis by a staggering $279 \%$ [24]. Credits: figure by I.A. Charitos.

\section{The Prevention and Counseling for STDs}

One main objective of the medical community is to contain epidemics and encourage preventative measures in all cases of STDs, such as congenital syphilis. It is important to underline that syphilis is a curable bacterial disease, for which adequate and effective therapies exist. Clinical and laboratory control is therefore necessary for correct diagnosis and therapy (such as antibiotics with probiotics, and other forms). Patients presenting with signs and symptoms consistent with STDs and/or with positive test serology must be treated according to international guidelines (without venturing into often-incorrect interpretations) $[25,26]$. Therefore, training and information programs are needed for healthcare professionals, for them to share the most appropriate information to the population, patients, and the partners of patients, for better sexual behavior. In this way, we will be able to increase early diagnoses, trace and treat the STDs early, and prevent epidemics $[27,28]$. Therefore, accurate information must be given to the patients (and to their partner(s) as well, if necessary) explaining the serological tests and treatments, and providing targeted counseling. Therefore, it is mandatory to (a) emphasize the importance of prophylaxis during sexual intercourse (such as condoms). (b) Highlight that all types of sexual relationships could lead to STD risks, (such as oral sex). (c) Emphasize the use of condoms during oral sex (especially to reduce HIV transmission risk; if they are not used, then individuals should at least be advised to avoid ejaculation in an oral cavity or sperm ingestion). (d) Explain the necessity for sexual abstinence during therapy, the execution of clinical checks, and laboratory tests. In addition, individuals should be made aware of the importance of the timing of serological controls (e.g., after one month, three months, six months, and one year from therapy, in the case of syphilis infection); that the incubation period is contagious, and that STDs (such as syphilis) do not give permanent immunity, i.e., individuals could be re-infected [28-30]. 


\section{Conclusions}

STDs have been known about in the medical field since ancient times. Today, with the progress of science, there are effective diagnosis and treatment methods to cure STDs. The medical community is currently paying special attention to STDs, as their transmissions have recently increased in almost every country, especially among young people and adolescents, despite there being adequate ways to prevent them, and satisfactory information from countless healthcare and sexual behavior campaigns. This leads to the conclusion that measures that are more drastic should be taken. Prevention, especially at a young age, is crucial for safer sexual behavior. As such, stable, consistent, valid, and timely sexual education in schools should be considered as an integral part of the pedagogical process. Moreover, adult family contributions also play an important role in adopting healthy sexual behaviors.

Author Contributions: Conceptualization, L.S. and M.C.; methodology, L.S. and M.C.; validation, L.S. and I.A.C.; investigation, M.C. and I.A.C.; resources, L.S.; data curation, L.S., M.C. and I.A.C.; writing-original draft preparation, I.A.C.; writing—review and editing, L.S.; supervision, LS.; project administration, L.S. All authors have read and agreed to the published version of the manuscript.

Funding: This research received no external funding.

Institutional Review Board Statement: Not applicable.

Conflicts of Interest: The authors declare no conflict of interest.

\section{References}

1. Garcia, M.R.; Wray, A.A. Sexually Transmitted Infections; StatPearls Publishing: Treasure Island, FL, USA, 2021. Available online: https:/ / www.ncbi.nlm.nih.gov/books / NBK560808/ (accessed on 31 October 2021).

2. Santacroce, L.; Bottalico, L.; Haxhirexha, K.; Topi, S.; Charitos, I.A. Pre-Chemistry Concepts and Medical Therapy among Ancient Physicians through the Pre-Socratic Philosophers. Endocr. Metab. Immune Disord. Drug. Targets 2020, 20, 1470-1477. [CrossRef] [PubMed]

3. Bottalico, L.; Charitos, I.A.; Kolveris, N.; D'Agostino, D.; Topi, S.; Ballini, A.; Santacroce, L. Philosophy and Hippocratic Ethic in Ancient Greek Society: Evolution of Hospital-Sanctuaries. Open Access Maced. J. Med. Sci. 2019, 13, 3353-3357. [CrossRef] [PubMed]

4. Walton, S.F.; Currie, B.J. Problems in diagnosing scabies, a global disease in human and animal populations. Clin. Microbiol. Rev. 2007, 20, 268-279. [CrossRef] [PubMed]

5. Romaní, J.; Romaní, M. Causes and Cures of Skin Diseases in the Work of Hildegard of Bingen. Actas Dermosifiliogr. 2017, 108, 538-543. [CrossRef] [PubMed]

6. Santacroce, L.; Bottalico, L.; Topi, S.; Castellaneta, F.; Charitos, I.A. The "Scourge of the Renaissance". A Short Review About Treponema pallidum infection. Endocr. Metab. Immune Disord. Drug Targets 2020, 20, 335-343. [CrossRef]

7. Waugh, M. The progress of venereology in Europe since the sixteenth century. Clin. Dermatol. 2002, 20, 119-121. [CrossRef]

8. Henry, R. Etymologia: Neisseria. Emerg. Infect. Dis. 2016, 22, 1141. Available online: https://wwwnc.cdc.gov/eid/article/22/6 /et-2206_article (accessed on 31 October 2021). [CrossRef]

9. Siracusano, S.; Silvestri, T.; Casotto, D. Sexually transmitted diseases: Epidemiological and clinical aspects in adults. Urologia 2014, 81, 200-208. [CrossRef] [PubMed]

10. Institute of Medicine (US) Committee on Prevention and Control of Sexually Transmitted Diseases. The Hidden Epidemic: Confronting Sexually Transmitted Diseases; Factors that Contribute to the Hidden Epidemic; Eng, T.R., Butler, W.T., Eds.; National Academies Press: Washington, DC, USA, 1997. Available online: https://www.ncbi.nlm.nih.gov/books/NBK232936/ (accessed on 31 October 2021).

11. European Center for Disease Prevention and Control (ECDC). Sexually Transmitted Infections in Europe 1990-2010. Available online: https:/ / www.ecdc.europa.eu/sites/portal/files/media/en/publications/Publications/201206-Sexually-TransmittedInfections-Europe-2010.pdf (accessed on 31 October 2021).

12. Aral, S.O.; Fenton, K.A.; Holmes, K.K. Sexually transmitted diseases in the USA: Temporal trends. Sex Transm. Infect. 2007, 83, 257-266. [CrossRef] [PubMed]

13. Da Ros, C.T.; Schmitt, C.D.S. Global epidemiology of sexually transmitted diseases. Asian J. Androl. 2008, 10, 110-114. [CrossRef] [PubMed]

14. European Center for Disease Prevention and Control (ECDC). Sexually Transmitted Infections in Europe 1990-2009. Available online: https://www.ecdc.europa.eu/sites/default/files/media/en/publications/Publications/110526_SUR_STI_in_Europe_ 1990-2009.pdf (accessed on 31 October 2021). 
15. World Health Organization (WHO). AIDS Epidemic Update on December 2004. Available online: https://data.unaids.org/pub/ report/2004/2004_epiupdate_en.pdf (accessed on 31 October 2021).

16. European Center for Disease Prevention and Control (ECDC). Annual Epidemiological Report 2012. Available online: https: / / www.ecdc.europa.eu/en/publications-data/annual-epidemiological-report-2012-2010-data (accessed on 31 October 2021).

17. Centers for Disease Control and Prevention USA. Sexually Transmitted Disease Surveillance 1999. Available online: https: //www.cdc.gov/std/stats/archive/Surv-1999-All.pdf (accessed on 31 October 2021).

18. European Centre for Disease Prevention and Control. Sexually Transmitted Infections in Europe 2013; ECDC: Stockholm, Sweden, 2015. Available online: https:/ / www.ecdc.europa.eu/en/publications-data/sexually-transmitted-infections-europe-2013\#nolink (accessed on 31 October 2021).

19. European Centre for Disease Prevention and Control. Annual Epidemiological Report on Communicable Diseases in Europe 2010; ECDC: Stockholm, Sweden, 2010. Available online: https:/ /www.ecdc.europa.eu/sites/default/files/media/en/publications/ Publications/1011_SUR_Annual_Epidemiological_Report_on_Communicable_Diseases_in_Europe.pdf (accessed on 31 October 2021).

20. European Centre for Disease Prevention and Control. Annual Epidemiological Report on Communicable Diseases in Europe.Sexually transmitted infections, EU/EEA. 2016. Available online: https://www.slideshare.net/ECDC_EU/sexually-transmitted-infectionseueea-2016 (accessed on 31 October 2021).

21. European Centre for Disease Prevention and Control. Annual Epidemiological Report on Communicable Diseases in Europe 2017. Available online: https:/ / www.ecdc.europa.eu/en/publications-data/presentation-annual-epidemiological-report-2017 -sexually-transmitted-diseases (accessed on 31 October 2021).

22. World Health Organization (WHO). Sexually transmitted infections (STIs). 2021. Available online: https://www.who.int/newsroom/fact-sheets/detail/sexually-transmitted-infections-(stis) (accessed on 31 October 2021).

23. Kreisel, K.M.; Spicknall, I.H.; Gargano, J.W.; Lewis, F.M.T.; Lewis, R.M.; Markowitz, L.E.; Roberts, H.; Johnson, A.S.; Song, R.; Cyr, S.B.S.; et al. Sexually Transmitted Infections Among US Women and Men: Prevalence and Incidence Estimates, 2018. Sex Transm. Dis. 2021, 48, 208-214. [CrossRef] [PubMed]

24. Centers for Disease Control and Prevention USA. Sexually Transmitted Disease Surveillance. Available online: https://www.cdc. gov/std/statistics/2019/announcement.htm (accessed on 31 October 2021).

25. Centers for Disease Control and Prevention USA. Sexually Transmitted Diseases Treatment Guidelines. 2015. Available online: https: / / www.cdc.gov/ mmwr/preview/mmwrhtml/rr6403a1.htm (accessed on 31 October 2021).

26. Ballini, A.; Santacroce, L.; Cantore, S.; Bottalico, L.; Dipalma, G.; Vito, D.; Saini, R.; Inchingolo, F. Probiotics Improve Urogenital Health in Women. Open Access Maced. J. Med. Sci. 2018, 6, 1845-1850. [CrossRef] [PubMed]

27. Shafer, C.W. STD prevention: Why limit ourselves to just an ounce? S D Med. 2015, 53-57.

28. Best, K. Good counseling vital for clients with STDs. Netw. Res. Triangle Park N.C. 1999, 19, 23-25. [PubMed]

29. Schirinzi, A.; Cazzolla, A.P.; Mascolo, E.; Palmieri, G.; Pesce, F.; Gesualdo, L.; Santacroce, L.; Ballini, A.; Lovero, R.; Di Serio, F. Determination of the Upper Reference Limit of Human Epididymis Secretory Protein 4 (HE4) in Healthy Male Individuals and Correlation with Renal and Fertility Markers. Endocr. Metab. Immune Disord. Drug Targets 2021, 21, 912-918. [CrossRef] [PubMed]

30. Henderson, J.T.; Senger, C.A.; Henninger, M.; Bean, S.I.; Redmond, N.; O'Connor, E.A. Behavioral Counseling Interventions to Prevent Sexually Transmitted Infections: Updated Evidence Report and Systematic Review for the US Preventive Services Task Force. JAMA 2020, 324, 682-699. [CrossRef] [PubMed] 